\title{
Functional differences between aggregated and dispersed insulin-producing cells
}

\author{
A. Chowdhury • O. Dyachok • A. Tengholm • S. Sandler • \\ P. Bergsten
}

Received: 9 March 2012 / Accepted: 12 March 2013 /Published online: 19 April 2013

(C) The Author(s) 2013. This article is published with open access at Springerlink.com

\begin{abstract}
Aims/hypothesis Beta cells situated in the islet of Langerhans respond more vigorously to glucose than do dissociated beta cells. Mechanisms for this discrepancy were studied by comparing insulin-producing MIN6 cells aggregated into pseudoislets with MIN6 monolayer cells and mouse and human islets.

Methods MIN6 monolayers, pseudoislets and mouse and human islets were exposed to glucose, $\alpha$-ketoisocaproic acid (KIC), pyruvate, KIC plus glutamine and the phosphatidylinositol 3-kinase (PI3K) inhibitors LY294002 or wortmannin. Insulin secretion (ELISA), cytoplasmic $\mathrm{Ca}^{2+}$ concentration $\left(\left[\mathrm{Ca}^{2+}\right]_{\mathrm{c}}\right.$; microfluorometry), glucose oxidation (radiolabelling), the expression of genes involved in mitochondrial metabolism (PCR) and the phosphorylation of insulin receptor signalling proteins (western blotting) were measured.

Results Insulin secretory responses to glucose, pyruvate, KIC and glutamine were higher in pseudoislets than monolayers and comparable to those of human islets. Glucose oxidation and genes for mitochondrial metabolism were upregulated in pseudoislets compared with single cells and monolayers, respectively. Phosphorylation at the inhibitory S636/639 site of IRS-1 was significantly higher in monolayers and dispersed human and mouse cells than pseudoislets and intact human and mouse islets. PI3K inhibition only slightly attenuated glucose-stimulated insulin secretion from monolayers, but substantially reduced that
\end{abstract}

Electronic supplementary material The online version of this article (doi:10.1007/s00125-013-2903-3) contains peer-reviewed but unedited supplementary material, which is available to authorised users.

A. Chowdhury $(\bowtie) \cdot$ O. Dyachok $\cdot$ A. Tengholm $\cdot$ S. Sandler $\cdot$ P. Bergsten

Department of Medical Cell Biology, Uppsala University,

Box 571, 75123, Uppsala, Sweden

e-mail: azazul.chowdhury@mcb.uu.se from pseudoislets and human and mouse islets without suppressing the glucose-induced $\left[\mathrm{Ca}^{2+}\right]_{\mathrm{c}}$ response.

Conclusions/interpretation We propose that islet architecture is critical for proper beta cell mitochondrial metabolism and IRS-1 signalling, and that PI3K regulates insulin secretion at a step distal to the elevation of $\left[\mathrm{Ca}^{2+}\right]_{\mathrm{c}}$.

Keywords Beta cell $\cdot \mathrm{Ca}^{2+} \cdot$ Insulin secretion $\cdot$ IRS-1 . Islets $\cdot$ Mitochondrial metabolism $\cdot$ PI3-kinase
Abbreviations
$\left[\mathrm{Ca}^{2+}\right]_{\mathrm{c}}$ Cytoplasmic $\mathrm{Ca}^{2+}$ concentration
GSIS Glucose-stimulated insulin secretion
KIC Alpha-ketoisocaproic acid
PDX1 Pancreatic and duodenal homeobox 1
PI3K Phosphotidylinositol 3-kinase

\section{Introduction}

Insulin secreted from the pancreatic beta cell is the main glucose-lowering hormone. The loss of beta cell function plays a key role in the development of both type 1 and 2 diabetes mellitus. The beta cell is located in the islets of Langerhans, which are scattered in the pancreas and comprise approximately $1 \%$ of the volume of the gland [1]. In addition to insulin-secreting beta cells, the islets also contain other hormone-producing cell types, including glucagon-, somatostatin- and pancreatic polypeptide-secreting cells, as well as non-endocrine cells [1]. This makes it important to consider the contribution of non-beta cells in beta cell islet experimentation.

The relative difficulties of isolating large numbers of primary islets, and their mixed cell populations, have made insulin-producing cell lines an important tool in beta cell research. The mouse-derived insulinoma MIN6 cell line is 
glucose-responsive [2], although the response is modest, with a typically twofold to fourfold rise in glucosestimulated insulin secretion (GSIS) [3]. A larger secretory response to a glucose challenge depends on the location of the beta cell in the islet [4]. When challenged with high glucose levels, dispersed islet cells secrete less insulin than beta cells within the intact islet [5]. Interestingly, when dispersed islet cells were allowed to reaggregate into isletlike structures, so-called pseudoislets, much of the secretory capacity was regained [6]. The strategy of allowing cells to aggregate was also attempted with MIN6 cells, which form cell clusters the size of primary islets [7]. Despite containing only insulin-producing cells, these MIN6 pseudoislets showed enhanced glucose responsiveness compared with MIN6 cells cultured in monolayers [7].

In the present study, we characterised the detailed dynamic insulin secretory response of MIN6 pseudoislets to different metabolisable and non-metabolisable secretagogues. The secretory phenotype was compared not only with that of MIN6 cells grown in monolayers, but also with that of human and mouse islets. We demonstrate that the superior secretory characteristics of MIN6 cells aggregated to form pseudoislets compared with MIN6 monolayers depended on mitochondrial metabolism and was related to differences in IRS-1 phosphorylation.

\section{Methods}

Cell culture Mouse insulinoma MIN6 monolayer cells were cultured in $250 \mathrm{ml}$ tissue culture flasks (Becton Dickson Labware, Franklin Lakes, NJ, USA) at $37^{\circ} \mathrm{C}\left(95 \% \mathrm{O}_{2}\right.$ and $5 \% \mathrm{CO}_{2}$ ) in DMEM (Invitrogen, Paisley, UK) as previously described [3]. MIN6 pseudoislets were prepared by aggregating $3 \times 10^{6}$ dispersed cells cultured in Petri dishes made of non-adherent plastic (Becton Dickson Labware) for 35 days using the same culture condition as for monolayers [7]. All experiments were performed between passages 20 and 30. Human islets were cultured for 4-8 days before experiments in CMRL medium containing $5.5 \mathrm{mmol} / \mathrm{l}$ glucose and supplemented with $10 \%$ FBS, $1 \%$ L-glutamine, $100 \mathrm{U} / \mathrm{ml}$ penicillin and $100 \mu \mathrm{g} / \mathrm{ml}$ streptomycin. Islets from the pancreases of $\mathrm{C} 57 \mathrm{~B} 1 / 6$ mice were isolated using collagenase. The mouse islets obtained were cultured for 2 days in RPMI 1640 (Invitrogen) medium containing $11.1 \mathrm{mmol} / 1$ glucose supplemented with $10 \%$ FBS, 100 units/ml penicillin and $100 \mu \mathrm{g} / \mathrm{ml}$ streptomycin.

To prepare the dispersed cells, groups of 100 human and mouse islets were dispersed in $0.5 \%$ trypsin for $10-12 \mathrm{~min}$ and 3-5 min, respectively, and then treated with DNase I (Qiagen GmbH, Hilden, Germany) for 2 min. The resulting cell suspensions were placed in poly-L-lysine-coated plates and cultured for $48 \mathrm{~h}$ in the respective culture medium. The use of human and mouse islets was approved by the local ethical committees (Dnr 2010/006 for human islets and Dnr C106/11 for mouse islets).

Insulin secretion Insulin secretion was measured from MIN6 monolayers and MIN6 pseudoislets as well as mouse and human islets. For static incubation experiments, $10^{5}$ MIN6 cells were seeded into 12-well tissue culture plates (Becton Dickson Labware) and cultured for 3 days. The cultured monolayer cells or groups of 20 pseudoislets or human islets were preincubated for $60 \mathrm{~min}$ at $37^{\circ} \mathrm{C}$ in $1 \mathrm{ml}$ KRB HEPES buffer consisting of $130 \mathrm{mmol} / \mathrm{l} \mathrm{NaCl}$, $4.8 \mathrm{mmol} / \mathrm{l} \mathrm{KCl}, 1.2 \mathrm{mmol} / 1 \mathrm{MgSO}_{4}, 1.2 \mathrm{mmol} / 1 \mathrm{KH}_{2} \mathrm{PO}_{4}$, $1.2 \mathrm{mmol} / 1 \mathrm{CaCl}_{2}, 5 \mathrm{mmol} / 1 \mathrm{NaHCO}_{3}$ and $5 \mathrm{mmol} / 1 \mathrm{HEPES}$, titrated to $\mathrm{pH} 7.4$ with $\mathrm{NaOH}$ and supplemented with $1 \mathrm{mg} / \mathrm{ml} \mathrm{BSA}$ and $2 \mathrm{mmol} / \mathrm{l}$ glucose. Subsequently, the cells were incubated in $1 \mathrm{ml}$ KRB HEPES buffer containing either 2 or $20 \mathrm{mmol} / 1$ glucose for $30 \mathrm{~min}$ at $37^{\circ} \mathrm{C}$. Aliquots $(200 \mu \mathrm{l})$ of medium were collected for determination of insulin secretion. Total protein was measured as previously described [3].

Insulin secretion was also measured dynamically from monolayer cells, groups of 20 pseudoislets and human and mouse islets by perifusing in the presence of 2 and $20 \mathrm{mmol} / \mathrm{l}$ glucose as previously described [8]. Individual pseudoislets and human islets were also perifused in 2 and $20 \mathrm{mmol} / \mathrm{l}$ glucose. For the dynamic insulin measurement, $5 \times 10^{4}$ MIN6 cells were attached to the central part of poly-L-lysinecoated coverslips and cultured for 3 days. The samples were collected at $2 \mathrm{mmol} / \mathrm{l}$ glucose during either $10 \mathrm{~min}$ for individual islets or $20 \mathrm{~min}$ for other preparations. Subsequently, the medium was exchanged to either $20 \mathrm{mmol} / \mathrm{l}$ glucose, $2 \mathrm{mmol} / \mathrm{l}$ pyruvate, $20 \mathrm{mmol} / \mathrm{l}$ alpha-ketoisocaproic acid (KIC), $10 \mathrm{mmol} / 1 \mathrm{KIC}$ plus $10 \mathrm{mmol} / \mathrm{l}$ glutamine, or $30 \mathrm{mmol} / 1$ $\mathrm{KCl}$, and sample collection was continued for another $20 \mathrm{~min}$. In some experiments, LY294002 $(50 \mu \mathrm{mol} / \mathrm{l})$ or wortmannin (100 nmol/l for monolayers, pseudoislets and mouse islets; $1 \mu \mathrm{mol} / 1$ for human islets) was introduced into the perifusion medium 30 min prior to sampling and was present throughout the experiment. Insulin was measured by ELISA as previously described [8].

Simultaneous measurements of insulin and cytoplasmic $\mathrm{Ca}^{2+}$ concentration For simultaneous measurements of insulin and cytoplasmic $\mathrm{Ca}^{2+}$ concentration $\left(\left[\mathrm{Ca}^{2+}\right]_{\mathrm{c}}\right)$, pseudoislets were loaded with $1 \mu \mathrm{mol} / 1$ Fura-2 LR acetoxymethyl ester (TEFLabs, Inc., Austin, TX, USA) by incubating them for $60 \mathrm{~min}$ at $37^{\circ} \mathrm{C}$ in KRB HEPES buffer containing $2 \mathrm{mmol} / 1$ glucose and $1 \mathrm{mg} / \mathrm{ml} \mathrm{BSA}$. After rinsing, groups of islets were allowed to attach to the central part of poly-L-lysine-coated coverslips. The chamber was placed on the stage of an inverted microscope (Eclipse TE2000U; Nikon, Tokyo, Japan). The pseudoislets were perifused for 
60 min with $2 \mathrm{mmol} / \mathrm{l}$ glucose in KRB HEPES buffer supplemented with $1 \mathrm{mg} / \mathrm{ml} \mathrm{BSA}$ at $37^{\circ} \mathrm{C}$ at a rate of $160 \mu \mathrm{l} / \mathrm{min}$. $\left[\mathrm{Ca}^{2+}\right]_{\mathrm{c}}$ was recorded by dual wavelength fluorometry as previously described [9]. During the $\left[\mathrm{Ca}^{2+}\right]_{\mathrm{c}}$ recordings, the perifusate was collected in $1 \mathrm{~min}$ intervals for subsequent insulin measurements.

To measure the effect of phosphatidylinositol 3-kinase (PI3K) inhibition, the attached pseudoislets were perifused for $30 \mathrm{~min}$ in $2 \mathrm{mmol} / \mathrm{l}$ glucose. Wortmannin $(100 \mathrm{nmol} / \mathrm{l})$ or LY294002 $(50 \mu \mathrm{mol} / 1)$ was subsequently added and perifusion continued for another $30 \mathrm{~min}$ before $\left[\mathrm{Ca}^{2+}\right]_{\mathrm{c}}$ was measured and fractions of perifusate were collected for insulin measurement in the continued presence of the inhibitors.

Western blotting To determine the levels of specific proteins, western blotting was performed on MIN6 monolayers, MIN6 pseudoislets and human and mouse islets with some modifications as previously described [3]. Immunoblotting was conducted with antibodies against IRS-1, IRS-2, phosphorylated (p)-IRS-1 S636/639, p-IRS-1 S612, p-IRS-1 S307, p-Akt (S473), p-Akt (T308), p-S6 ribosomal protein (S235/236), total Akt, total S6 ribosomal protein, pancreatic and duodenal homeobox 1 (PDX1; Cell Signaling, Danvers, MA, USA), glucokinase, GLUT2 and actin (Santa Cruz Biotechnology, Santa Cruz, CA, USA). The immunoreactive bands were imaged with the Fluor-S MultiImager MAX (Bio-Rad, Hercules, CA, USA) and quantified with Quantity One software (Bio-Rad).

$m R N A$ expression by real-time PCR Total RNA was extracted from MIN6 monolayers and pseudoislets using the RNeasy Mini Kit (Qiagen $\mathrm{GmbH}$ ). The reverse transcription reaction was performed with $1 \mu \mathrm{g}$ total RNA using $\mathrm{RT}^{2}$ First-Strand Kit (Qiagen $\left.\mathrm{GmbH}\right)$. The cDNA obtained was processed by quantitative real-time reverse transcriptase PCR of 84 genes involved in the mitochondrial electron transport chain and oxidative phosphorylation complexes, and 12 housekeeping genes including internal controls using the $\mathrm{RT}^{2}$ Profiler PCR Array kit $\left(\mathrm{RT}^{2}\right.$ Profiler PCR Array Mouse Mitochondrial Energy Metabolism, PAMM-008; Qiagen $\mathrm{GmbH}$ ) and a Stratagene Mx3000p real-time PCR system (Stratagene, La Jolla, CA, USA). The $\Delta \Delta \mathrm{C}_{\mathrm{t}}$-based fold change in pseudoislets compared with monolayers was obtained by uploading the raw threshold cycle data to an integrated web-based software package ( $\mathrm{RT}^{2}$ Profiler PCR Array Data Analysis version 3.5; Qiagen $\mathrm{GmbH}$ ) for the PCR array system, using the following formula: fold change $=2^{-\Delta \Delta \mathrm{C}_{\mathrm{t}}}$, where $\Delta \Delta \mathrm{C}_{\mathrm{t}}=\Delta \mathrm{C}_{\mathrm{t}}$ (pseudoislets) $-\Delta \mathrm{C}_{\mathrm{t}}$ (monolayers), and $\Delta \mathrm{C}_{\mathrm{t}}=\mathrm{C}_{\mathrm{t}}$ (gene of interest) $-\mathrm{C}_{\mathrm{t}}$ (average of housekeeping genes). Based on PCR array results, some genes were validated by real-time PCR. The real-time PCR product was quantified by measuring SYBR Green (Agilent
Technologies, Santa Clara, CA, USA) fluorescent dye incorporation with ROX dye reference and normalised to the housekeeping genes $\beta$-actin $(A c t b)$, glyceraldehyde-3phosphate dehydrogenase (GAPDH), hypoxanthine guanine phosphoribosyl transferase (Hprt) and heat shock protein $90 \mathrm{kDa}$ alpha (cytosolic), class B member 1 (Hsp90ab1). The primers used are listed in electronic supplementary material (ESM) Table 1.

Glucose oxidation rate MIN6 monolayer cells and pseudoislets were harvested, in triplicate per observation, and transferred to incubation vials containing KRB HEPES buffer, supplemented with $20 \mathrm{mmol} / 1$ glucose containing $(15.5 \mathrm{GBq} / \mathrm{mol}) \mathrm{D}-\left[\mathrm{U}_{-}{ }^{14} \mathrm{C}\right]$ glucose. The vials were incubated for $90 \mathrm{~min}$ at $37^{\circ} \mathrm{C}$ under an atmosphere of $95 / 5 \% \mathrm{O}_{2} / \mathrm{CO}_{2}$, with slow shaking. Metabolism was arrested by adding $17 \mu \mathrm{mol} / 1$ antimycin A. Subsequently, the released labelled ${ }^{14} \mathrm{CO}_{2}$ was trapped in $250 \mu$ l hyamine hydroxide during incubation at $37^{\circ} \mathrm{C}$ for $2 \mathrm{~h}$, and the radioactivity was measured by liquid scintillation counting. Cell numbers in aliquots of the harvested MIN6 monolayers were counted in a Becton Dickinson FACSCalibur flow cytometer (Becton Dickinson, San Jose, CA, USA). As for the pseudoislets, triplicate groups of 50 islets harvested in parallel to those incubated with labelled glucose were dispersed as described above, and the cell number was counted in the flow cytometer. The glucose oxidation rates were subsequently expressed per number of cells.

Data analysis Results are presented as means \pm SEM. Statistical significance for the difference between two conditions was analysed using the Student's $t$ test. Multiple comparisons between different groups were assessed using ANOVA followed by Bonferroni's post hoc test. A value $p<$ 0.05 was considered statistically significant.

\section{Results}

GSIS In static incubation, pseudoislet insulin release increased approximately sixfold when the glucose concentration was raised from 2 to $20 \mathrm{mmol} / \mathrm{l}$ glucose, whereas for the monolayers it doubled (Fig. 1). The magnitude of the secretory response of human islets was similar to that of the MIN6 pseudoislets.

Perifusion of individual MIN6 pseudoislets in the presence of $2 \mathrm{mmol} / \mathrm{l}$ glucose showed insulin oscillations with a periodicity of $4.3 \pm 0.3 \mathrm{~min}$, which were similar to those observed for human islets $(4.1 \pm 0.4 \mathrm{~min})$ (ESM Fig. 1). Augmentation of the glucose concentration to $20 \mathrm{mmol} / \mathrm{l}$ increased the amplitude of the insulin pulses without 


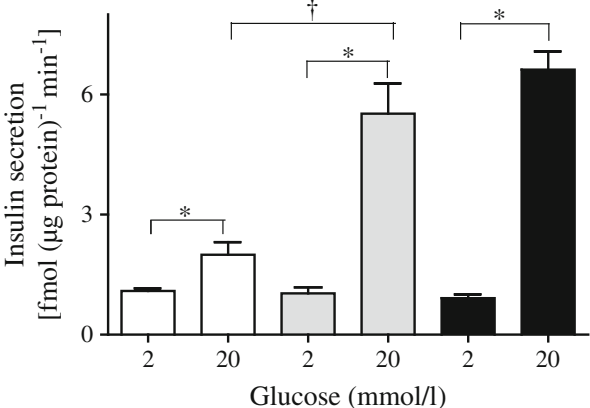

Fig. 1 Insulin secretion from MIN6 monolayers (white bars), MIN6 pseudoislets (grey bars) and human islets (black bars) exposed to 2 or $20 \mathrm{mmol} / 1$ glucose for $30 \mathrm{~min}$. The level of insulin released to the medium was measured and normalised to protein level. Results are means \pm SEM of five separate experiments. ${ }^{*} p<0.05$ compared with $2 \mathrm{mmol} / 1$ glucose; ${ }^{\dagger} p<0.05$ compared with pseudoislets altering the periodicity of the pseudoislets and human islets (ESM Fig. 1).

Insulin secretion dynamics in response to nutrient and depolarising stimuli Dynamic insulin secretion from pseudoislets in response to $20 \mathrm{mmol} / \mathrm{l}$ glucose, pyruvate, $\mathrm{KIC}$, KIC in combination with glutamine, and high $\mathrm{KCl}$ was analysed and compared with that generated from monolayer cells and human islets (Fig. 2, Table 1). Secreted insulin level was determined in the presence of $2 \mathrm{mmol} / \mathrm{l}$ glucose for $10 \mathrm{~min}$ prior to the elevation of glucose or the introduction of other secretagogues (basal), during the first $10 \mathrm{~min}$ after stimulation, corresponding to first-phase insulin secretion and for ten subsequent minutes corresponding to second-phase insulin secretion. A rise in the glucose concentration to $20 \mathrm{mmol} / \mathrm{l}$ caused a significant increase in
Fig. 2 Insulin secretion from monolayers (dotted line) and groups of pseudoislets (solid line) and human islets (dashed line) in the presence of glucose (Glu) (a), pyruvate (Pyr) (b), $\mathrm{KIC}$ (c), KIC plus glutamine (d), or a high concentration of $\mathrm{KCl}$ (e). Insulin released to the media was measured and normalised to protein level. Results are representative of five separate experiments a

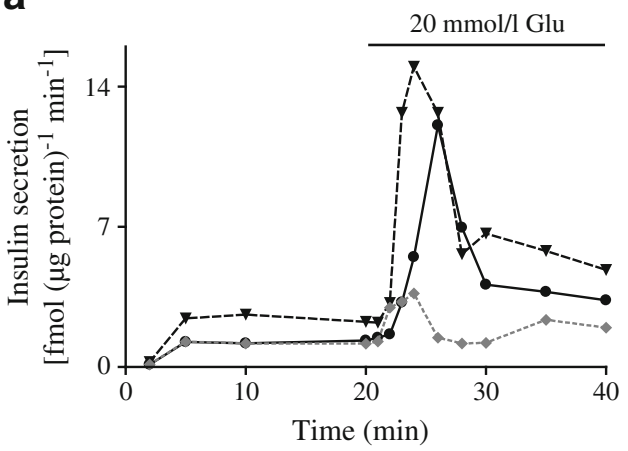

C

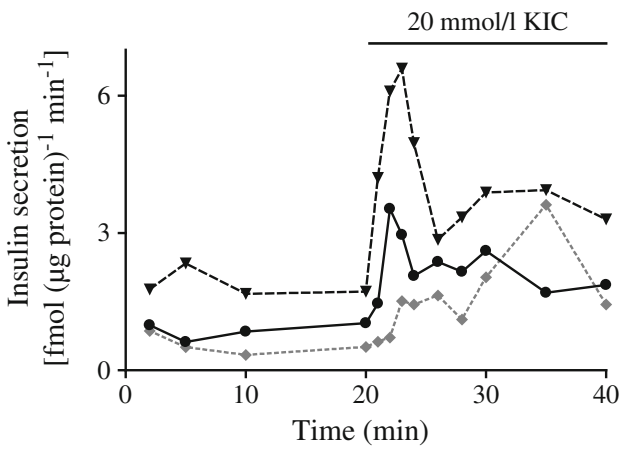

e

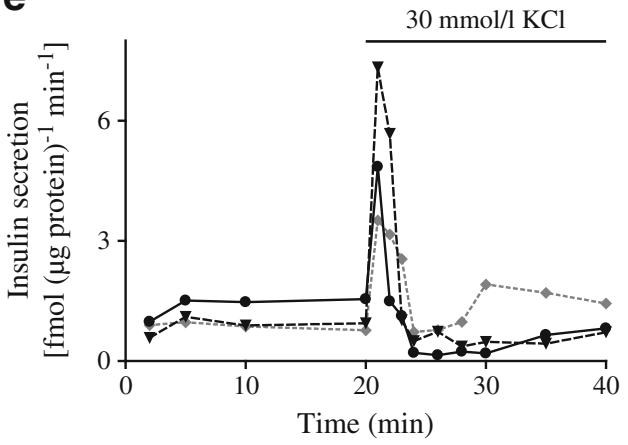

b

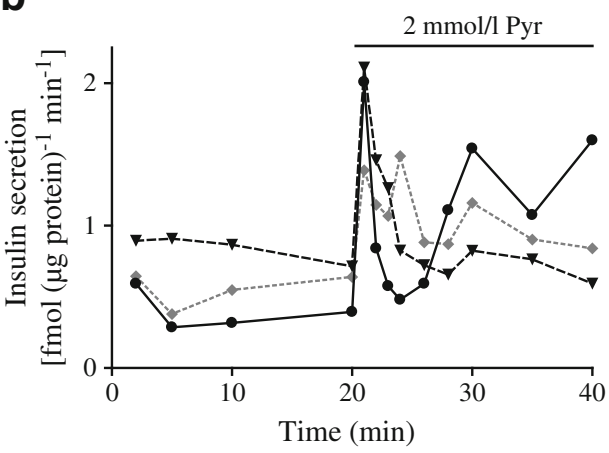

d

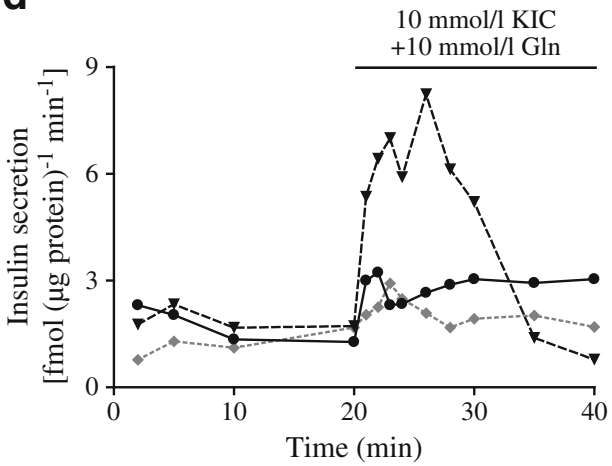


Table 1 Insulin secretion from MIN6 monolayer cells, pseudoislets and human islets in the presence of different secretagogues

\begin{tabular}{lccl}
\hline Secretagogue & \multicolumn{2}{c}{ Insulin secretion [fmol $(\mu \mathrm{g} \text { protein })^{-1}$ ] } \\
\cline { 2 - 4 } & $\begin{array}{l}\text { Monolayer } \\
\text { cells }\end{array}$ & Pseudoislets & $\begin{array}{l}\text { Human } \\
\text { islets }\end{array}$ \\
\hline Glu 2 mmol/1 & $5.1 \pm 0.8$ & $6.4 \pm 0.1$ & $8.4 \pm 0.6$ \\
Glu 20 mmol/1, first & $7.5 \pm 0.8^{*^{\dagger}}$ & $36.1 \pm 0.7^{*}$ & $54.3 \pm 8.6^{*}$ \\
phase & $6.9 \pm 0.8^{* \dagger}$ & $45.1 \pm 12.3^{*}$ & $43.6 \pm 7.3^{*}$ \\
Glu 20 mmol/1, & $6.8 \pm 0.2$ & $6.3 \pm 0.8$ & $11.5 \pm 3.2$ \\
second phase & $8.4 \pm 0.2$ & $11.3 \pm 3.7^{*}$ & $14.7 \pm 1.3^{\dagger}$ \\
Glu 2 mmol/1 & $8.0 \pm 0.9^{\dagger}$ & $15.7 \pm 1.7^{*}$ & $10.7 \pm 2.9$ \\
Pyr first phase & $7.1 \pm 0.4$ & $8.7 \pm 1.6$ & $16.7 \pm 6.2$ \\
Pyr second phase & $7.9 \pm 0.3^{\dagger}$ & $21.5 \pm 2.5^{*}$ & $42.9 \pm 10.2^{* \dagger}$ \\
Glu 2 mmol/1 & $11.9 \pm 0.6^{*}$ & $15.3 \pm 2.3^{*}$ & $39.3 \pm 14.5^{* \dagger}$ \\
KIC first phase & $7.9 \pm 0.2$ & $7.1 \pm 0.16$ & $14.4 \pm 4.6$ \\
KIC second phase & $13.6 \pm 0.5^{*}$ & $17.2 \pm 2.3^{*}$ & $59.0 \pm 3.5^{* \dagger}$ \\
Glu 2 mmol/1 & $11.9 \pm 0.5^{* \dagger}$ & $20.5 \pm 2.5^{*}$ & $43.2 \pm 13.8^{* \dagger}$ \\
KIC + Gln first phase & & \\
KIC + Gln second & $4.4 \pm 0.1$ & $8.5 \pm 0.61$ & $13.0 \pm 4.5$ \\
phase & $10.1 \pm 0.8^{*}$ & $15.2 \pm 0.3^{*}$ & $37.8 \pm 8.9^{* \dagger}$ \\
Glu 2 mmol/1 & $12.1 \pm 0.3^{*}$ & $7.2 \pm 2.7$ & $6.1 \pm 0.6^{*}$ \\
KCl first phase & & & \\
KCl second phase & & & \\
\hline
\end{tabular}

Results are means \pm SEM of between five and eight separate experiments, which were obtained by calculating the area under the curve from each group of the experiments in Fig. 3

Cells and islets were perifused in the presence of 2 or $20 \mathrm{mmol} / \mathrm{l}$ glucose (Glu), $2 \mathrm{mmol} / 1$ pyruvate (Pyr), $20 \mathrm{mmol} / 1 \mathrm{KIC}$, and $10 \mathrm{mmol} / 1 \mathrm{KIC}$ plus $10 \mathrm{mmol} / \mathrm{l}$ glutamine $(\mathrm{Gln})$ or $30 \mathrm{mmol} / \mathrm{l} \mathrm{KCl}$. Secreted insulin was measured for $10 \mathrm{~min}$ at $2 \mathrm{mmol} / \mathrm{l}$ glucose and in the initial (first phase) and subsequent (second phase) $10 \mathrm{~min}$ after the introduction of secretagogues

${ }^{*} p<0.05$ compared with $2 \mathrm{mmol} / 1$ glucose; ${ }^{\dagger} p<0.05$ compared with pseudoislets

both the first and second phases of insulin secretion in the pseudoislets, monolayers and human islets (Fig. 2a, Table 1). The augmentation of insulin secretion from the pseudoislets was significantly higher than that from the monolayers and similar to that observed from human islets.

When $2 \mathrm{mmol} / \mathrm{l}$ pyruvate was introduced, a small, initial and transient increase in insulin secretion was observed for all preparations (Fig. 2b). In the pseudoislets, but not in the monolayer cells and human islets, pyruvate induced a significant rise in second-phase insulin secretion (Table 1).

KIC $(20 \mathrm{mmol} / \mathrm{l})$ induced significant first- and secondphase insulin release from the pseudoislets but increased only the second phase of insulin secretion from the monolayers. In the human islets, KIC elicited a pronounced rise in both first- and second-phase insulin secretion. When the pseudoislets were exposed to $10 \mathrm{mmol} / \mathrm{K} \mathrm{KIC}$ plus $10 \mathrm{mmol} / \mathrm{l}$ glutamine, first- and second-phase insulin secretion was somewhat augmented compared with secretion observed in the presence of KIC alone (Fig. 2d, Table 1). In monolayer cells, the combination caused a small but significant firstphase insulin secretion. In human islets, the combination elicited an accentuated first-phase and second-phase insulin secretion. In the pseudoislets, depolarisation by $\mathrm{KCl}$ caused a prompt transient response involving only first-phase secretion (Fig. 2e, Table 1). A similar but more pronounced first-phase secretory response was observed in human islets. In contrast, monolayer cells showed a significant increase in the second-phase insulin secretory response as well (Table 1).

Expression of genes related to mitochondrial respiration and electron transport To investigate how genes encoding components of the mitochondrial electron transport and oxidative phosphorylation complex were affected in the pseudoislets and MIN6 monolayers, the transcript levels of 84 genes were determined where 77 genes were expressed in both pseudoislets and monolayer cells; a majority (76\%) of the genes showed a 1.4-fold or more increase in the pseudoislets compared with the monolayers (Table 2). Genes that showed at least a twofold up- or downregulation in the array were also validated by quantitative RT-PCR (Table 2).

Glucose oxidation MIN6 pseudoislets had a markedly higher glucose oxidation rate at $20 \mathrm{mmol} / \mathrm{l}$ glucose $(3.57 \pm$ 0.63 [pmol glucose $/$ cell $\times 90 \mathrm{~min}])$ compared with cells growing in monolayers $(1.09 \pm 0.34$ [pmol glucose/cell $\times$ $90 \mathrm{~min}])(p<0.006$ using an unpaired Student's $t$ test; $n=6$ in both groups). The technique did not allow a direct comparison between pseudoislets and adherent monolayer cells, and we cannot exclude the possibility that the suspended cells would have shown a different rate of oxidation compared with the monolayers.

Expression of beta cell proteins Levels of proteins connected with beta cell differentiation and function were measured in the pseudoislets, monolayers and human islets. In agreement with previous reports $[7,10]$ a similar insulin content was observed in the pseudoislets and monolayer cells (ESM Fig. 2). These levels were, however, only half those obtained for the human islets. Levels of PDX1, glucokinase and GLUT2 did not differ between the monolayers, pseudoislets and human islets (ESM Fig. 3). PDX-1 protein and glucokinase mRNA levels have been demonstrated to be similar in MIN6 cells and mouse islets [11, 12] In addition, both MIN6 cells and mouse islets express high levels of GLUT2 mRNA [13].

IRS-1 phosphorylation and PI3K activity The total levels of IRS-1 in the pseudoislets, as well as the total levels of IRS-2 (data not shown), were no different from those obtained for 
Table 2 Expression of mitochondrial respiration and electron transport genes in MIN6 monolayer cells and MIN6 pseudoislets
Results are means \pm SEM of four separate experiments

Differential mRNA expression levels of genes encoding the components of mitochondrial electron transport and oxidative phosphorylation in MIN6 pseudoislets compared with monolayers was measured by PCR array and validated by quantitative RT-PCR (qRT-PCR) ${ }^{*} p<0.05$ compared with MIN6 monolayer cells

\begin{tabular}{|c|c|c|c|c|c|}
\hline $\begin{array}{l}\text { Gene } \\
\text { symbol }\end{array}$ & $\begin{array}{l}\text { Fold regulation } \\
\text { (PCR array) }\end{array}$ & $\begin{array}{l}\text { Validation } \\
\text { (qRT-PCR) }\end{array}$ & $\begin{array}{l}\text { Gene } \\
\text { symbol }\end{array}$ & $\begin{array}{l}\text { Fold regulation } \\
\text { (PCR array) }\end{array}$ & $\begin{array}{l}\text { Validation } \\
\text { (qRT-PCR) }\end{array}$ \\
\hline Lhpp & 1.4658 & & Ndufa 7 & 2.3978 & $3.10 \pm 0.42$ \\
\hline Atp $4 a$ & -1.1394 & & $N d u f a 8$ & 2.0163 & $1.85 \pm 0.13^{*}$ \\
\hline Atp5a1 & 1.8554 & & Ndufabl & -2.2788 & $1.92 \pm 0.34^{*}$ \\
\hline Atp $5 b$ & 1.7553 & & Ndufb10 & 2.073 & $1.96 \pm 0.35^{*}$ \\
\hline Atp5c1 & 1.7432 & & $N d u f b 2$ & 1.2939 & \\
\hline Atp5d & 1.6955 & & $N d u f b 3$ & 1.2156 & \\
\hline Atp5f1 & 1.8046 & & $N d u f b 4$ & 1.5175 & \\
\hline Atp5g1 & 1.2498 & & $N d u f b 5$ & 1.4557 & \\
\hline Atp5g2 & 1.8046 & & $N d u f b 6$ & 1.6264 & \\
\hline Atp5g3 & 2.0874 & $1.61 \pm 0.08^{*}$ & $N d u f b 7$ & 1.4658 & \\
\hline Atp $5 h$ & 1.3395 & & $N d u f b 8$ & 1.6955 & \\
\hline Atp5j & 1.7798 & & $N d u f b 9$ & 1.9208 & \\
\hline Atp5j2 & 1.6378 & & $N d u f c 1$ & 2.0303 & $1.88 \pm 0.34^{*}$ \\
\hline Atp5o & 1.7073 & & $N d u f_{c} 2$ & 1.7675 & \\
\hline Atp6v0a2 & 1.5602 & & $N d u f_{s} 1$ & -1.1878 & \\
\hline Atp6v1c2 & 3.4623 & $2.48 \pm 0.59 *$ & $N d u f_{s} 2$ & 1.1032 & \\
\hline Bcs 11 & 1.7675 & & $N d u f_{s} 3$ & 1.7922 & \\
\hline Cox 11 & 2.2372 & $1.73 \pm 0.18^{*}$ & $N d u f_{s} 4$ & -1.0485 & \\
\hline Cox4il & 2.6239 & $2.50 \pm 0.69^{*}$ & $N d u f_{s} 5$ & 1.1742 & \\
\hline Cox $5 a$ & 1.1421 & & Ndufs6 & 2.0445 & $3.58 \pm 0.83^{*}$ \\
\hline Cox $5 b$ & 1.6264 & & $N d u f s 7$ & 2.2528 & $2.54 \pm 0.47^{*}$ \\
\hline Cox6al & 1.5281 & & $N d u f s 8$ & 1.9885 & \\
\hline Cox6a2 & -3.383 & $-2.37 \pm 0.28^{*}$ & $N d u f v 1$ & 2.0874 & $3.17 \pm 0.20^{*}$ \\
\hline Cox6b1 & 1.4257 & & $N d u f v 2$ & 2.3648 & $2.42 \pm 0.35^{*}$ \\
\hline Cox6b2 & 1.9885 & & Ndufv3 & 2.0587 & $4.41 \pm 0.56^{*}$ \\
\hline $\operatorname{Cox} 6 c$ & 1.8172 & & Oxall & 2.2842 & $2.14 \pm 0.38^{*}$ \\
\hline Cox7a2 & 1.1824 & & Ppal & -1.8382 & \\
\hline Cox7a2l & 2.9317 & $3.17 \pm 0.70^{*}$ & Ppa2 & 1.285 & \\
\hline$C o x 7 b$ & 1.571 & & Sdha & 2.073 & $1.56 \pm 0.17 *$ \\
\hline Cox $8 a$ & 2.1019 & $1.82 \pm 0.31 *$ & $S d h b$ & 1.4061 & \\
\hline $\operatorname{Cox} 8 c$ & 1.6955 & & Sdhc & 1.4159 & \\
\hline Cycl & 1.285 & & Sdhd & 1.8298 & \\
\hline Ndufal & 1.9476 & & Uqcr 11 & 1.2326 & \\
\hline Ndufalo & 1.507 & & Uqcrcl & 1.9612 & \\
\hline Ndufa 2 & 1.7073 & & Uqcrc2 & 1.9612 & \\
\hline Ndufa 3 & 1.604 & & Uqcrfs 1 & 1.8683 & \\
\hline Ndufa4 & 1.2326 & & Uqcrh & 2.1166 & $3.5 \pm 0.6^{*}$ \\
\hline Ndufa5 & 1.8298 & & Uqcrq & 1.8426 & \\
\hline Ndufa6 & 2.3161 & $2.77 \pm 0.52 *$ & & & \\
\hline
\end{tabular}

the monolayer cells (Fig. 3a). Levels of the inhibitory phosphorylation at S636/639 of IRS-1 were lower in pseudoislets than monolayer cells (Fig. 3b), but no differences were observed for inhibitory sites S307 and S612 (data not shown). We also measured whether S636/639 phosphorylation affected PI3K activity by measuring the level of Akt phosphorylation at T308 as this site was reported to correlate with PI3K activity in other cell types [14, 15]. In MIN6 monolayers, phosphorylation of Akt at site T308 was significantly reduced compared with that seen in the pseudoislets (Fig. 4). When phosphorylation of IRS-1 at S636/639 was measured in intact and dispersed human and mouse islets, levels were lower in intact islets than dispersed cells (Fig. 3d,f).

To determine whether the differences in p-IRS- 1 at S636/639 were contributing to the observed differences in 
a
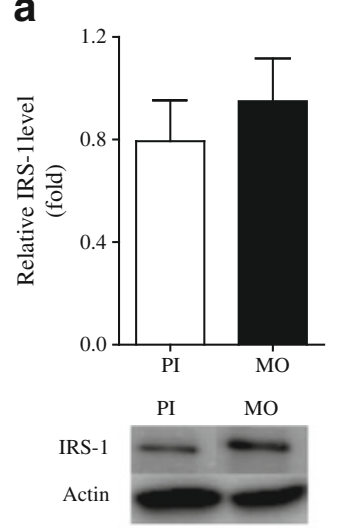

C

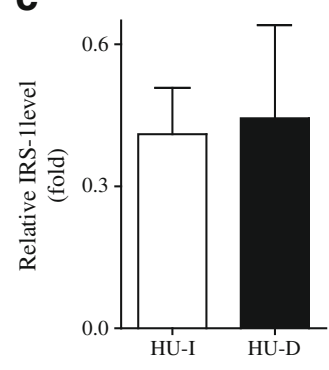

HU-I HU-D

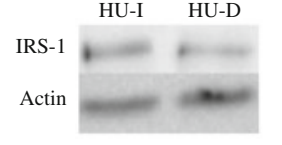

e

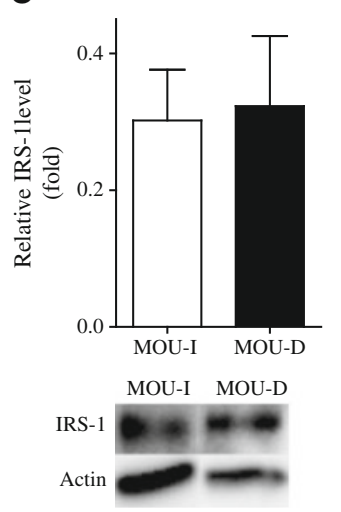

b
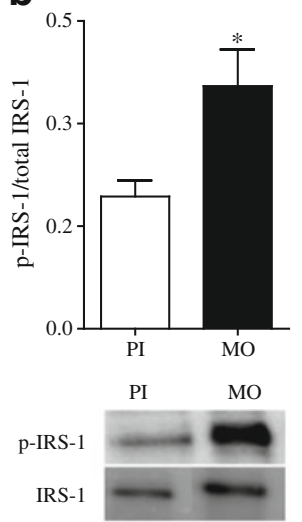

d
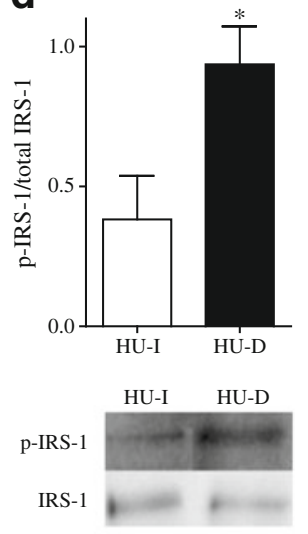

f

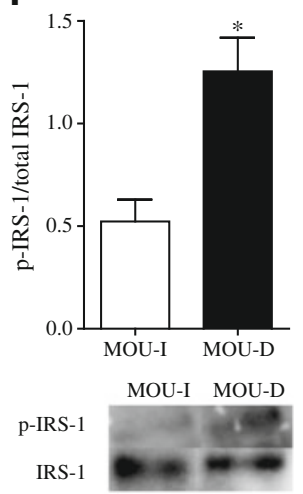

Fig. 3 Levels of total IRS-1 and IRS-1 phosphorylated at S636/639 (p-IRS-1) were measured by western blotting in MIN6 pseudoislets (PI) and monolayers (MO) (a,b), human islets (HU-I) and dispersed human islets (HU-D) (c,d), and mouse islets (MOU-I) and dispersed mouse islets (MOU-D) (e,f). Protein levels were normalised to actin for IRS-1, and total IRS-1 for p-IRS1 (S636/639). Results are means \pm SEM of four or five separate experiments. ${ }^{*} p<0.05$ compared with pseudoislets or intact islets

secretory patterns via PI3K, we measured insulin secretion in the presence of the PI3K inhibitors LY294002 and wortmannin. PI3K inhibition was further studied by measuring the phosphorylation of Akt. LY294002 $(50 \mu \mathrm{mol} / \mathrm{l})$

blocked Akt phosphorylation in all preparations. Similar results were obtained with $50 \mathrm{nmol} / \mathrm{l}$ wortmannin in MIN6 cells, pseudoislets and mouse islets, whereas $1 \mu \mathrm{mol} / 1$ wortmannin was required to obtain inhibition in human islets (data not shown). The inhibitor LY294002, which was introduced 30 min prior to glucose elevation, decreased GSIS from the pseudoislets and human islets but did not affect the already low secretion from the monolayer cells during static incubation (ESM Fig. 4). In dynamic measurements, basal insulin secretion from pseudoislets, monolayer cells and human and mouse islets perifused in the presence of $2 \mathrm{mmol} / 1$ glucose was not affected by either LY294002 or wortmannin (Fig. 5, Table 3). When the glucose concentration was increased to $20 \mathrm{mmol} / \mathrm{l}$, insulin secretion from the pseudoislets and human and mouse islets exposed to either of the inhibitors was significantly reduced in both the first and second phases (Fig. 5b-d, Table 3). In contrast, a reduction in the first but not the second, phase of GSIS was observed in monolayer cells (Fig. 5a, Table 3). Total levels of phosphorylation of Akt and S6 ribosomal protein, which were located downstream of PI3K, did not differ between monolayers and pseudoislets (data not shown). When MIN6 monolayers and pseudoislets were treated with LY294002 for $60 \mathrm{~min}$, an increased level of IRS-1 phosphorylation at S636/639 was observed in pseudoislets compared with monolayer cells (Fig. 6), but no differences were observed at S307 and S612 (data not shown).

Next, we investigated the extent to which the reduction in GSIS observed in the pseudoislets exposed to PI3K inhibitors involved alterations in $\left[\mathrm{Ca}^{2+}\right]_{\mathrm{c}}$. In control pseudoislets, a rise in the glucose concentration from 2 to $20 \mathrm{mmol} / \mathrm{l}$ elicited a transient decrease in $\left[\mathrm{Ca}^{2+}\right]_{\mathrm{c}}$ followed by a marked increase that peaked within 2 min after the elevation of glucose (Fig. 7a, Table 4). After the initial peak, $\left[\mathrm{Ca}^{2+}\right]_{\mathrm{c}}$ decreased to a plateau from which distinct oscillations

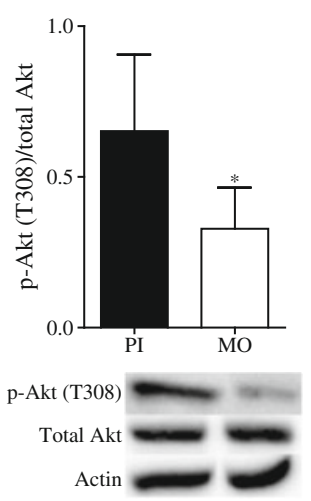

Fig. 4 Levels of Akt phosphorylated at T308 were measured by western blotting in MIN6 pseudoislets (PI) and monolayers (MO). Protein levels were normalised to actin for Akt, and total Akt for p-Akt (T308). Results are means \pm SEM of four separate experiments. ${ }^{*} p<0.05$ compared with pseudoislets 
Fig. 5 Glucose (Glu)stimulated insulin secretion from MIN6 monolayers (a), pseudoislets (b), human islets (c) and mouse islets (d) in the absence (solid line) or presence of the PI3K inhibitors wortmannin (grey dotted line) or LY294002 (black dashed line). Insulin released to the medium was measured and normalised to protein. Results are representative of four or five separate experiments a

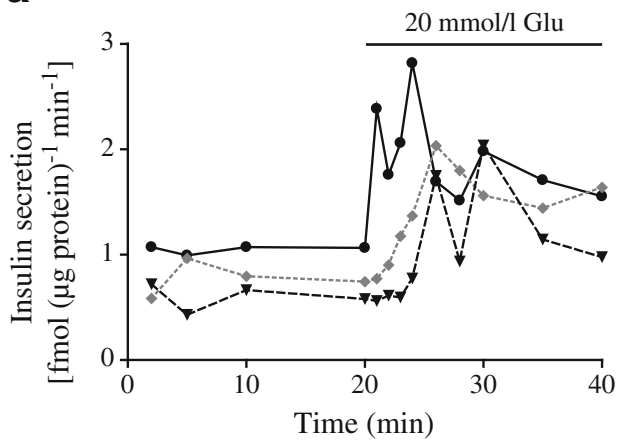

C

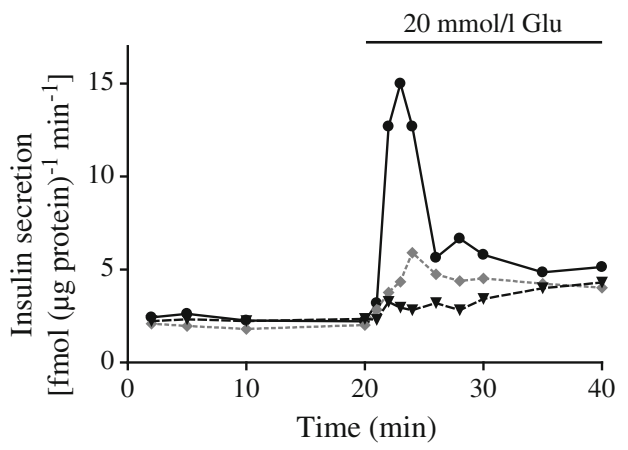

b

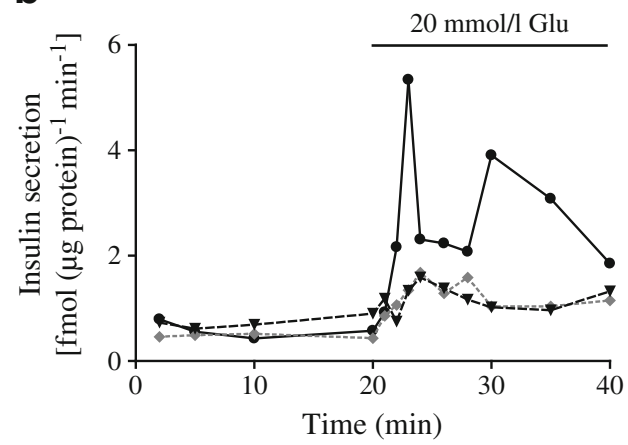

d

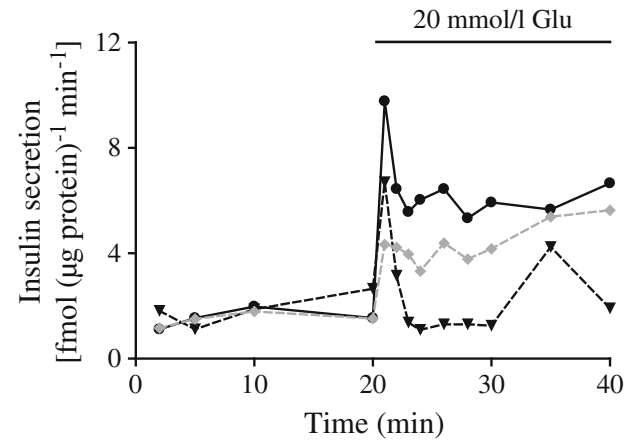

$(\sim 2 / \mathrm{min})$ appeared. The $\left[\mathrm{Ca}^{2+}\right]_{\mathrm{c}}$ response was paralleled by a pronounced initial insulin secretory peak followed by oscillatory insulin levels (Fig. 7a). In pseudoislets pretreated with LY294002, a blunted GSIS was paralleled by a $\left[\mathrm{Ca}^{2+}\right]_{\mathrm{c}}$ response that was similar to control but with lower basal $\left[\mathrm{Ca}^{2+}\right]_{\mathrm{c}}$ and a higher frequency of the glucose-induced oscillations (Fig. 7 b, Table 4 ). $\left[\mathrm{Ca}^{2+}\right]_{\mathrm{c}}$ was also recorded in pseudoislets pretreated with wortmannin. Although this drug markedly reduced insulin secretion (Fig. 5b), it had no effect on $\left[\mathrm{Ca}^{2+}\right]_{\mathrm{c}}$ (Table 4). The effects of acute inhibition of PI3K on $\left[\mathrm{Ca}^{2+}\right]_{\mathrm{c}}$ were also investigated in the pseudoislets. While LY294002 markedly accelerated the $\left[\mathrm{Ca}^{2+}\right]_{\mathrm{c}}$ oscillations (Fig. $7 \mathrm{c}$ ), there was no effect of wortmannin (Fig. 7d).

Table 3 Effects of PI3K inhibition on GSIS from MIN6 monolayer cells, pseudoislets and human and mouse islets

\begin{tabular}{|c|c|c|c|c|}
\hline \multirow[t]{2}{*}{ PI3K inhibitor } & \multicolumn{4}{|c|}{ Insulin secretion [fmol ( $\mu$ g protein $\left.)^{-1}\right]$} \\
\hline & Monolayer & Pseudoislets & Human islets & Mouse islets \\
\hline Glu 2 mmol/1 & $7.4 \pm 2.6$ & $6.2 \pm 0.8$ & $8.6 \pm 0.3$ & $5.3 \pm 0.9$ \\
\hline Glu $20 \mathrm{mmol} / \mathrm{l}$ first phase & $18.2 \pm 1.5^{*}$ & $40.1 \pm 4.5^{*}$ & $65.1 \pm 6.4^{*}$ & $31.5 \pm 10.2^{*}$ \\
\hline Glu $20 \mathrm{mmol} / 1$ second phase & $12.7 \pm 1.8^{*}$ & $55.5 \pm 11.9^{*}$ & $51.7 \pm 5.5^{*}$ & $43.5 \pm 11.3^{*}$ \\
\hline Glu $2 \mathrm{mmol} / \mathrm{l}+\mathrm{W}$ & $5.9 \pm 0.6$ & $5.8 \pm 0.4$ & $9.7 \pm 0.4$ & $9.6 \pm 0.9$ \\
\hline Glu $20 \mathrm{mmol} / 1+\mathrm{W}$ first phase & $9.4 \pm 1.3^{* \dagger}$ & $12.9 \pm 0.6^{* \dagger}$ & $20.5 \pm 0.5^{* \dagger}$ & $19.3 \pm 7.3 *^{\dagger}$ \\
\hline Glu $20 \mathrm{mmol} / \mathrm{l}+\mathrm{W}$ second phase & $10.8 \pm 1.8^{*}$ & $13.2 \pm 0.8^{* \dagger}$ & $17.6 \pm 0.5^{*^{\dagger}}$ & $22.7 \pm 5.2 *^{\dagger}$ \\
\hline Glu 2 mmol/1 + LY & $4.4 \pm 1.0$ & $8.3 \pm 0.3$ & $11.9 \pm 2.3$ & $8.3 \pm 1.2$ \\
\hline Glu $20 \mathrm{mmol} / 1+$ LY first phase & $11.6 \pm 1.9^{* \dagger}$ & $12.6 \pm 0.3 * \dagger$ & $22.7 \pm 3.1 * \dagger$ & $23.9 \pm 2.7^{* \dagger}$ \\
\hline Glu $20 \mathrm{mmol} / 1$ + LY second phase & $11.4 \pm 2.5^{*}$ & $11.5 \pm 0.2 *^{\dagger}$ & $19.1 \pm 2.9^{* \dagger}$ & $27.0 \pm 5.2 *^{\dagger}$ \\
\hline
\end{tabular}

Results are means \pm SEM of four or five separate experiments, which were obtained by calculating the area under the curve from Fig. 7

Cells and islets, exposed or not to the PI3K inhibitor wortmannin (W) or LY294002 (LY), were perifused. Secreted insulin was measured for 10 min at $2 \mathrm{mmol} / \mathrm{l}$ glucose (Glu) and in the initial (first phase) and subsequent (second phase) $10 \mathrm{~min}$ after raising the glucose concentration to $20 \mathrm{mmol} / \mathrm{l}$ ${ }^{*} p<0.05$ compared with $2 \mathrm{mmol} / 1$ glucose; ${ }^{\dagger} p<0.05$ compared with control 

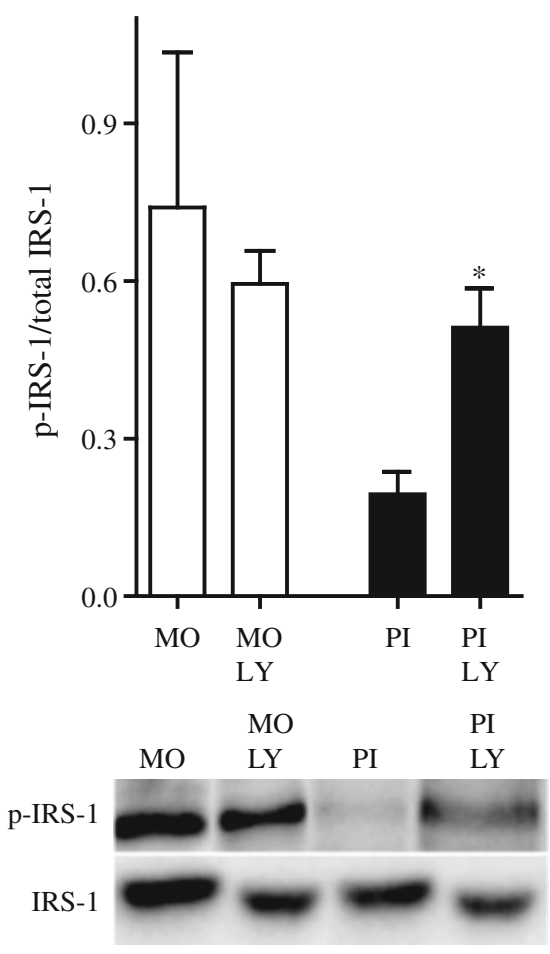

Fig. 6 Levels of IRS-1 phosphorylated at S636/639 (p-IRS-1) were measured by western blotting and normalised to total IRS-1 in MIN6 monolayers and pseudoislets with or without the PI3K inhibitor LY294002 (LY). Results are representative of five separate experiments. ${ }^{*} p<0.05$ compared with control. MO, monolayers; PI pseudoislets

\section{Discussion}

The question of why beta cells situated in the islet of Langerhans perform better than separated beta cells was addressed using insulin-secreting MIN6 cells arranged as pseudoislets or monolayers [7, 10]. A number of mechanisms, including intercellular communication by direct cellcell contact and an exchange of small molecules through gap junctions and through paracrine effects have been suggested to explain the phenomenon [7, 10, 16-18]. Indeed, in MIN6 pseudoislets, the calcium-dependent cell adhesion molecule E-cadherin and the gap junction protein connexin 36, which are required for proper insulin secretion, were upregulated compared with monolayer cells [7, 18]. In addition, increases in ins 1 mRNA levels were higher in the pseudoislets than the monolayers [19]. In the present study, MIN6 cells grown as pseudoislets showed a higher secretory capacity in response to glucose, in agreement with previous reports $[7,16]$. The notion of the insulin secretory characteristics of pseudoislets being similar to those of primary islets was further strengthened when the detailed secretory dynamics were investigated in the pseudoislets. Pulsatile insulin secretion was observed from pseudoislets, with pulse durations and amplitude regulation by glucose similar to those observed for primary islets [20-22]. The enhanced secretory characteristics of MIN6 pseudoislets in the present study involved both first- and second-phase insulin secretion, which were equally increased compared with the monolayer cells, in agreement with a previous report [10].

Impaired glucokinase activity and a lowered expression of GLUT2 have been connected with impaired insulin secretion $[23,24]$. The similar levels of these two proteins observed in the present and a previous study [25] suggest that the causes for the reduced secretion observed in monolayer cells lie distal to the initial steps of glucose metabolism. When pyruvate was administered extracellularly, the tricarboxylic acid induced insulin secretion from pseudoislets. The inability of pyruvate to elicit insulin secretion has been connected with low levels of the monocarboxylate transporter as well as a low expression of lactate dehydrogenase in the beta cell $[26,27]$. KIC is a mitochondrial substrate and acts as a potent insulin secretagogue [28]. The keto acid induced both first- and secondphase of insulin secretion from MIN6 pseudoislets [7]. When glutamine was also included, insulin secretion was enhanced from MIN6 pseudoislets but not to the same degree as was observed for human islets.

In this context, species differences cannot be ruled out. Direct comparisons of secretory responses between pseudoislets and mouse islets for some of the secretagogues used here and in a previous study [16] showed that the secretory responses were equivalent. For the remaining secretagogues, mouse islet secretory characteristics have been studied [29, 30] but not directly compared with those of MIN6 pseudoislets. Rather than performing a direct comparison between MIN6 pseudoislets and mouse islets for the latter secretagogues, we conducted these experiments with human islets. This choice was based on the fact that there are no studies in which the secretory characteristics of MIN6 pseudoislets and human islets have been directly compared.

In this comparison, we could not exclude the influence of non-beta cells in the human islets as such an influence is present [31] and is exemplified by studies showing that glutamine can stimulate glucagon secretion [32] and that pyruvate is preferentially oxidised in non-beta cells in both mouse [33] and human [34] islets. In addition, the extent to which alpha cells influence insulin secretion from pseudoislets has been addressed [35]. Based on these results and the observation that genes encoding the mitochondrial electron transport and oxidative phosphorylation complex as well as glucose oxidation were upregulated in pseudoislets compared with monolayers, we propose that enhanced mitochondrial metabolism contributed to the improved secretory capacity of cells in the pseudoislets.

In addition to enhanced metabolism, cell aggregation seems to be associated with alterations in IRS phosphorylation. Paracrine insulin signalling can be envisaged to be more pronounced when cells are aggregated in the islet-like 
a

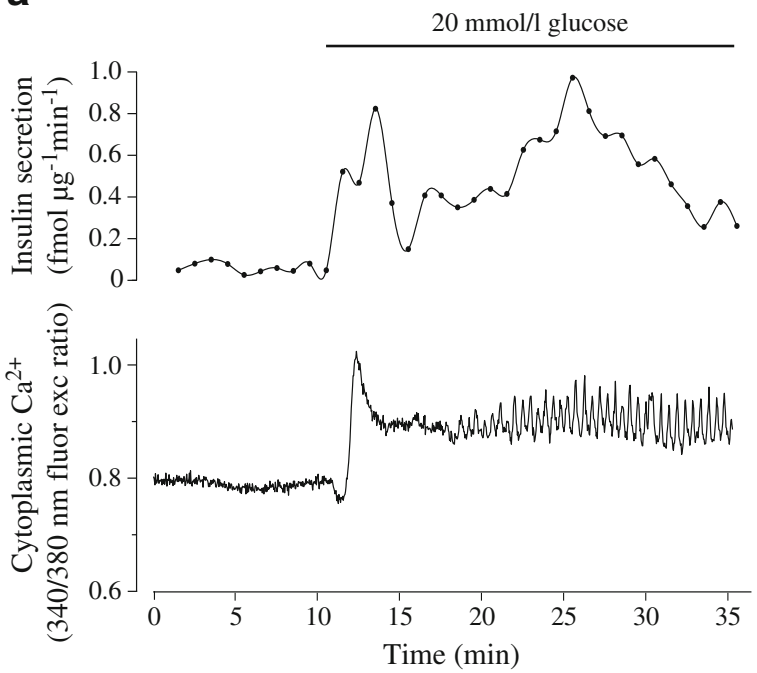

C

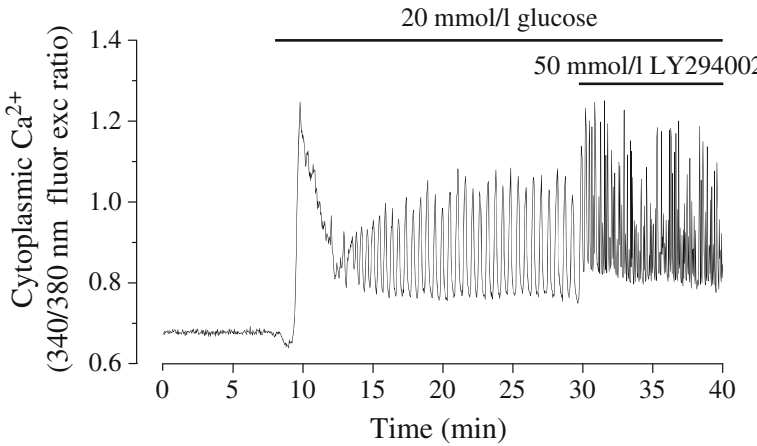

Fig. 7 Glucose-induced changes in $\left[\mathrm{Ca}^{2+}\right]_{\mathrm{c}}$ and insulin secretion in MIN6 pseudoislets exposed to PI3K inhibitors. Simultaneous recordings of $\left[\mathrm{Ca}^{2+}\right]_{\mathrm{c}}$ and insulin release in control (a) or LY294002-treated (prior to and during perifusion) pseudoislets (b). Changes in $\left[\mathrm{Ca}^{2+}\right]_{\mathrm{c}}$ in the pseudoislets after acute exposure to LY94002 (c) or wortmannin b

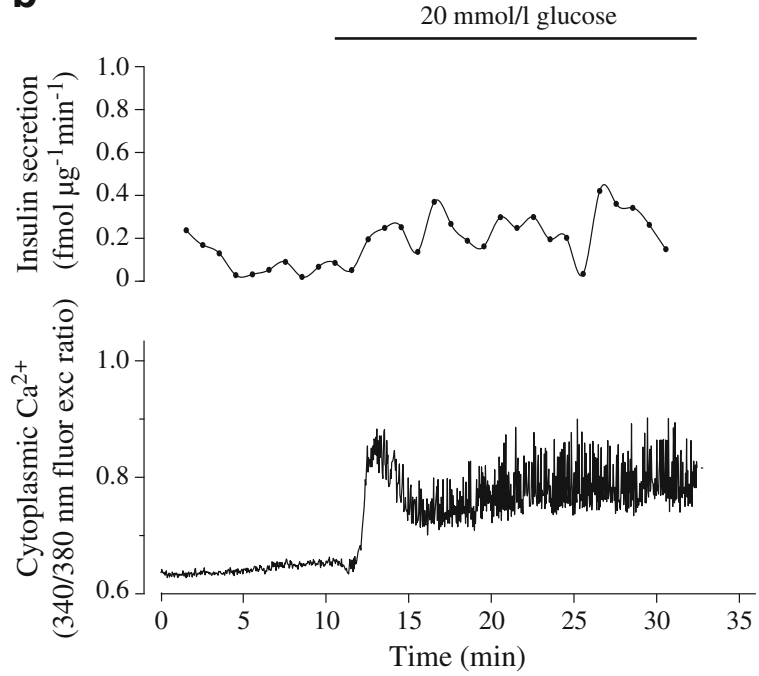

d

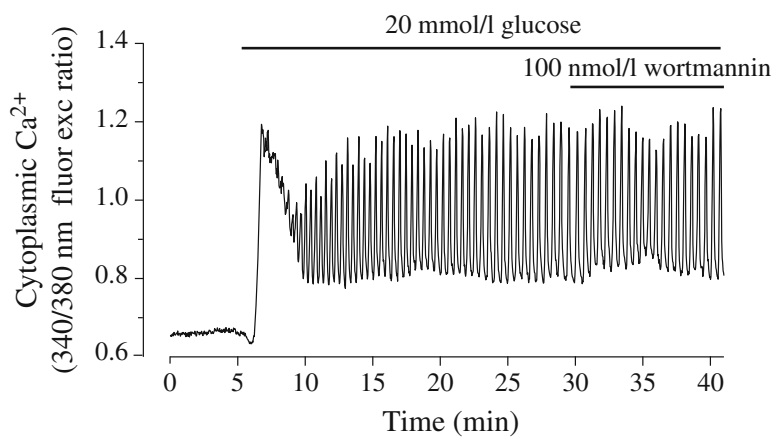

(d). Whereas the parallel recordings of insulin and $\left[\mathrm{Ca}^{2+}\right]_{\mathrm{c}}$ are representative of three independent experiments, the $\left[\mathrm{Ca}^{2+}\right]_{\mathrm{c}}$ recordings are representative of 26 (a), 13 (b), 7 (c) and 8 (d) pseudoislets, respectively, from between two and eight independent experiments; fluor exc, fluorescence excitation

Table 4 Effects of PI3K inhibition on glucose-induced $\left[\mathrm{Ca}^{2+}\right]_{\mathrm{c}}$ responses in MIN6 pseudoislets

\begin{tabular}{lccc}
\hline Measurement & Control $(n=26)$ & LY pretreatment $(n=13)$ & W pretreatment $(n=6)$ \\
\hline Basal level (nmol/l) & $118 \pm 5$ & $88 \pm 9^{*}$ & $102 \pm 5$ \\
Initial lowering (nmol/l) & $16 \pm 4$ & $7 \pm 1$ & $15 \pm 1$ \\
Response delay (min) & $1.37 \pm 0.03$ & $1.52 \pm 0.09$ & $1.34 \pm 0.06$ \\
Glucose-induced peak amplitude (nmol/l) & $133 \pm 11$ & $134 \pm 25$ & $176 \pm 12$ \\
Average stimulated level (nmol/l) & $180 \pm 4$ & $148 \pm 18$ & $199 \pm 7$ \\
Oscillation frequency $\left(\mathrm{min}^{-1}\right)$ & $2.18 \pm 0.09$ & $8.68 \pm 0.56^{*}$ & $2.74 \pm 0.06$ \\
\hline
\end{tabular}

Results are means \pm SEM for the number of pseudoislets indicated

$\left[\mathrm{Ca}^{2+}\right]_{\mathrm{c}}$ was measured in pseudoislets during an increase in the glucose concentration from 2 (basal) to 20 (stimulated) mmol/1 in the absence (control) or presence of LY294002 (LY) or wortmannin (W). Basal $\left[\mathrm{Ca}^{2+}\right]_{\mathrm{c}}$, the magnitude of the glucose-induced initial lowering of $\left[\mathrm{Ca}^{2+}\right]_{\mathrm{c}}$, the time between the elevation of the glucose concentration and the increase in $\left[\mathrm{Ca}^{2+}\right]_{\mathrm{c}}$, the amplitude of the initial glucose-induced increase in $\left[\mathrm{Ca}{ }^{2+}\right]_{\mathrm{c}}$, the average $\left[\mathrm{Ca}^{2+}\right]_{\mathrm{c}}$ under stimulated conditions as well as the frequency of glucose-induced $\left[\mathrm{Ca}^{2+}\right]_{\mathrm{c}}$ oscillations were quantified for each pseudoislet

${ }^{*} p<0.05$ compared with control 
structures, and we therefore wanted to investigate the insulin signalling pathway. Insulin secreted from beta cells binds to the insulin receptor, from which the signal is transduced via IRSs. The IRS proteins have multiple effects on the beta cell, including on survival via the PI3K/Akt pathway and on insulin gene transcription via PI3K/mTOR/p70s6 kinase [36-38]. It has been reported that manipulation of IRS-1 levels affects both the secretion and synthesis of insulin $[39,40]$. Although we observed no significant differences in the total levels of the IRS proteins in the present study, levels of the inhibitory serine phosphorylation site S636/S639 of IRS-1 were higher in monolayers than pseudoislets. The differential IRS-1 phosphorylation at site $\mathrm{S} 636 / 639$ is also proposed to contribute to the increased insulin secretion observed with pseudoislets and monolayer cells. Such serine/threonine phosphorylations uncouple the IRS proteins from their upstream and downstream effectors [41].

In human skeletal muscle cells, increased S636 phosphorylation of IRS-1 led to a reduced association of IRS-1 with PI3K [42]. A similar mechanism may be present in beta cells, since inhibitors of PI3K significantly reduced firstphase insulin secretion from pseudoislets and human islets but had only minor effects on the secretory patterns of monolayer cells. In accordance with this finding, PI3K inhibition has previously been reported to decrease the first phase of insulin secretion from MIN6 monolayers and mouse islets [43]. In contrast, other studies have suggested that PI3K inhibition results in increased GSIS [44-47]. Differences in experimental design may account for some of the discrepancy. In support for a role of PI3K as a positive regulator of insulin secretion, mouse models lacking expression of PI3K regulatory subunits [48] or of the catalytic subunit of the type 1B PI3K isoform [49] show reduced GSIS. PI3K inhibition does not, however, affect glucose metabolism $[44,50]$. Our study showed that the suppression of insulin secretion by PI $3 \mathrm{~K}$ inhibitors could not be explained by a reduction in $\left[\mathrm{Ca}^{2+}\right]_{\mathrm{c}}$, and PI3K seems to act at a distal step of the secretory process. Accordingly, wortmannin had no influence on the $\left[\mathrm{Ca}^{2+}\right]_{\mathrm{c}}$ responses, and the increased frequency of $\left[\mathrm{Ca}^{2+}\right]_{\mathrm{c}}$ oscillations caused by LY294002 is probably related to the ability of this compound to block voltage-gated $\mathrm{K}^{+}$channels ( $\mathrm{Kv}$ channels) in $\beta$-cells [44].

Acute inhibition of PI3K by wortmannin has previously been demonstrated not to have any effect on glucose metabolism or ATP content [44, 50]. Thus, there is no evidence for a direct causal link between the changes in metabolism and IRS-1 phosphorylation observed between MIN6 pseudoislets and monolayer cells. In conclusion, the present study indicates that enhanced mitochondrial metabolism and the differential phosphorylation of IRS-1 contribute towards the enhanced secretory capacity of beta cells situated in islets compared with dissociated beta cells.
Acknowledgements We would like to thank U. Landegren and M. Kamali-Moghaddam (Department of Immunology, Genetics and Pathology, Uppsala University, Uppsala, Sweden) for assistance with the PCR array.

Funding Grants from the Swedish Medical Research Council (72X14019, 67X-14643), Swedish Diabetes Association, Family Ernfors Foundation, EFSD/MSD, Novo-Nordisk Foundation and Uppsala University supported the study.

Duality of interest The authors declare there is no duality of interest associated with this manuscript.

Contribution statement AC performed secretory, PCR and western blot experiments and participated in study design, data analysis, interpretation and writing of the manuscript. OD designed the $\left[\mathrm{Ca}^{2+}\right]_{\mathrm{c}}$ experiment and participated in the acquisition of data, data analysis and writing of the manuscript. AT participated in $\left[\mathrm{Ca}^{2+}\right]_{\mathrm{c}}$ data analysis and manuscript writing. SS participated in the design of the glucose oxidation experiment, acquisition of data, data analysis and manuscript writing. PB participated in the study design, data interpretation, manuscript writing and overall supervision of the study. All authors critically revised and approved the final version of the manuscript.

Open Access This article is distributed under the terms of the Creative Commons Attribution Noncommercial License which permits any noncommercial use, distribution, and reproduction in any medium, provided the original author(s) and the source are credited.

\section{References}

1. Orci L, Unger RH (1975) Functional subdivision of islets of Langerhans and possible role of D cells. Lancet 2:1243-1244

2. Miyazaki JI, Araki K, Yamato E et al (1990) Establishment of a pancreatic beta-cell line that retains glucose-inducible insulinsecretion: special reference to expression of glucose transporter isoforms. Endocrinology 127:126-132

3. Thörn K, Bergsten P (2010) Fatty acid-induced oxidation and triglyceride formation is higher in insulin-producing MIN6 cells exposed to oleate compared to palmitate. J Cell Biochem 111:497-507

4. Pipeleers D, Intveld P, Maes E, Vandewinkel M (1982) Glucose-induced insulin release depends on functional cooperation between islet cells. Proc Natl Acad Sci USA Biol Sci 79:7322-7325

5. Salomon D, Meda P (1986) Heterogeneity and contact-dependent regulation of hormone secretion by individual B cells. Exp Cell Res 162:507-520

6. Hopcroft DW, Mason DR, Scott RS (1985) Insulin secretion from perifused rat pancreatic pseudoislets. In Vitro Cell Dev Biol 21:421-427

7. Hauge-Evans AC, Squires PE, Persaud SJ, Jones PM (1999) Pancreatic beta-cell-to-beta-cell interactions are required for integrated responses to nutrient stimuli: enhanced $\mathrm{Ca} 2+$ and insulin secretory responses of MIN6 pseudoislets. Diabetes 48:1402-1408

8. Bergsten P, Hellman B (1993) Glucose-induced amplitude regulation of pulsatile insulin secretion from individual pancreatic islets. Diabetes 42:670-674

9. Dyachok O, Tufveson G, Gylfe E (2004) $\mathrm{Ca}^{2+}$-induced $\mathrm{Ca}^{2+}$ release by activation of inositol 1,4,5-trisphosphate receptors in primary pancreatic $\beta$-cells. Cell Calcium 36:1-9

10. Luther MJ, Hauge-Evans A, Souza KL et al (2006) MIN6 betacell-beta-cell interactions influence insulin secretory responses to nutrients and non-nutrients. Biochem Biophys Res Commun 343:99-104 
11. Alejandro EU, Lim GE, Mehran AE et al (2011) Pancreatic betacell Raf-1 is required for glucose tolerance, insulin secretion, and insulin 2 transcription. FASEB J 25:3884-3895

12. Quintens R, Hendrickx N, Lemaire K, Schuit F (2008) Why expression of some genes is disallowed in beta-cells. Biochem Soc Trans 36:300-305

13. Ishihara H, Asano T, Tsukuda K et al (1993) Pancreatic beta cell line MIN6 exhibits characteristics of glucose metabolism and glucose-stimulated insulin secretion similar to those of normal islets. Diabetologia 36:1139-1145

14. Alessi DR, James SR, Downes CP et al (1997) Characterization of a 3-phosphoinositide-dependent protein kinase which phosphorylates and activates protein kinase Balpha. Curr Biol 7:261-269

15. Stokoe D, Stephens LR, Copeland T et al (1997) Dual role of phosphatidylinositol-3,4,5-trisphosphate in the activation of protein kinase B. Science 277:567-570

16. Kelly C, Guo H, McCluskey JT, Flatt PR, McClenaghan NH (2010) Comparison of insulin release from MIN6 pseudoislets and pancreatic islets of Langerhans reveals importance of homotypic cell interactions. Pancreas 39:1016-1023

17. Dahl U, Sjodin A, Semb H (1996) Cadherins regulate aggregation of pancreatic $\beta$-cells in vivo. Development 122:2895-2902

18. Rogers GJ, Hodgkin MN, Squires PE (2007) E-cadherin and cell adhesion: a role in architecture and function in the pancreatic islet. Cell Physiol Biochem 20:987-994

19. Roderigo-Milne H, Hauge-Evans AC, Persaud SJ, Jones PM (2002) Differential expression of insulin genes 1 and 2 in MIN6 cells and pseudoislets. Biochem Biophys Res Commun 296:589-595

20. Bergsten P, Hellman B (1993) Glucose-induced cycles of insulin release can be resolved into distinct periods of secretory activity. Biochem Biophys Res Commun 192:1182-1188

21. Lin JM, Fabregat ME, Gomis R, Bergsten P (2002) Pulsatile insulin release from islets isolated from three subjects with type 2 diabetes. Diabetes 51:988-993

22. Song SH, Kjems L, Ritzel R et al (2002) Pulsatile insulin secretion by human pancreatic islets. J Clin Endocrinol Metab 87:213-221

23. Tinto N, Zagari A, Capuano M et al (2008) Glucokinase gene mutations: structural and genotype-phenotype analyses in MODY children from South Italy. PLoS One 3:e1870

24. Ban N, Yamada Y, Someya Y et al (2002) Hepatocyte nuclear factor- $1 \alpha$ recruits the transcriptional co-activator $\mathrm{p} 300$ on the GLUT2 gene promoter. Diabetes 51:1409-1418

25. Hauge-Evans AC, Squires PE, Belin VD et al (2002) Role of adenine nucleotides in insulin secretion from MIN6 pseudoislets. Mol Cell Endocrinol 191:167-176

26. Zhao C, Wilson MC, Schuit F, Halestrap AP, Rutter GA (2001) Expression and distribution of lactate/monocarboxylate transporter isoforms in pancreatic islets and the exocrine pancreas. Diabetes 50:361-366

27. Sekine N, Cirulli V, Regazzi R et al (1994) Low lactatedehydrogenase and high mitochondrial glycerol phosphate dehydrogenase in pancreatic $\beta$-cells: potential role in nutrient sensing. J Biol Chem 269:4895-4902

28. Mohammed JS, Wang Y, Harvat TA, Oberholzer J, Eddington DT (2009) Microfluidic device for multimodal characterization of pancreatic islets. Lab Chip 9:97-106

29. MacDonald MJ (2002) Differences between mouse and rat pancreatic islets: succinate responsiveness, malic enzyme, and anaplerosis. Am J Physiol Endocrinol Metab 283:E302-E310

30. Welsh M, Hellerstrom C, Andersson A (1982) Respiration and insulin release in mouse pancreatic islets. Effects of L-leucine and 2-ketoisocaproate in combination with $\mathrm{D}$-glucose and Lglutamine. Biochim Biophys Acta 721:178-184

31. Pipeleers D, Kiekens R, Ling Z, Wilikens A, Schuit F (1994) Physiologic relevance of heterogeneity in the pancreatic beta-cell population. Diabetologia 37(Suppl 2):S57-S64
32. Kuhara T, Ikeda S, Ohneda A, Sasaki Y (1991) Effects of intravenous infusion of 17 amino acids on the secretion of GH, glucagon, and insulin in sheep. Am J Physiol 260:E21-E26

33. Hellman B, Idahl LA, Lernmark A, Sehlin J, Taljedal IB (1974) The pancreatic beta-cell recognition of insulin secretagogues. Comparisons of glucose with glyceraldehyde isomers and dihydroxyacetone. Arch Biochem Biophys 162:448-457

34. Henquin JC, Dufrane D, Nenquin M (2006) Nutrient control of insulin secretion in isolated normal human islets. Diabetes 55:3470-3477

35. Brereton H, Carvell MJ, Persaud SJ, Jones PM (2007) Islet alphacells do not influence insulin secretion through cell-cell contact. Diabet Med 24:30-30

36. Leibiger IB, Brismar K, Berggren PO (2010) Novel aspects on pancreatic beta-cell signal-transduction. Biochem Biophys Res Commun 396:111-115

37. Burks DJ, White MF (2001) IRS proteins and beta-cell function. Diabetes 50(Suppl 1):S140-S145

38. Boura-Halfon S, Zick Y (2009) Phosphorylation of IRS proteins, insulin action, and insulin resistance. Am J Physiol Endocrinol Metab 296:E581-E591

39. Kulkarni RN, Winnay JN, Daniels M et al (1999) Altered function of insulin receptor substrate-1-deficient mouse islets and cultured beta-cell lines. J Clin Invest 104:R69-R75

40. Aspinwall CA, Qian WJ, Roper MG, Kulkarni RN, Kahn CR, Kennedy RT (2000) Roles of insulin receptor substrate-1, phosphatidylinositol 3-kinase, and release of intracellular $\mathrm{Ca} 2+$ stores in insulin-stimulated insulin secretion in beta-cells. J Biol Chem 275:22331-22338

41. Zick Y (2001) Insulin resistance: a phosphorylation-based uncoupling of insulin signaling. Trends Cell Biol 11:437-441

42. Bouzakri K, Roques M, Gual P et al (2003) Reduced activation of phosphatidylinositol-3 kinase and increased serine 636 phosphorylation of insulin receptor substrate-1 in primary culture of skeletal muscle cells from patients with type 2 diabetes. Diabetes 52:1319-1325

43. Aoyagi K, Ohara-Imaizumi M, Nishiwaki C, Nakamichi Y, Nagamatsu S (2010) Insulin/phosphoinositide 3-kinase pathway accelerates the glucose-induced first-phase insulin secretion through TrpV2 recruitment in pancreatic $\beta$-cells. Biochem J 432:375-386

44. El-Kholy W, MacDonald P, Lin JH et al (2003) The phosphatidylinositol 3-kinase inhibitor LY294002 potently blocks Kv currents in beta cells via a direct mechanism. Diabetes 52:A368A368

45. Hagiwara S, Sakurai T, Tashiro F et al (1995) An inhibitory role for phosphatidylinositol 3-kinase in insulin secretion from pancreatic B cell line MIN6. Biochem Biophys Res Commun 214:51-59

46. Eto K, Yamashita T, Tsubamoto Y et al (2002) Phosphatidylinositol 3-kinase suppresses glucose-stimulated insulin secretion by affecting post-cytosolic $\left[\mathrm{Ca}^{2+}\right]$ elevation signals. Diabetes 51:87-97

47. Zawalich WS, Zawalich KC (2000) A link between insulin resistance and hyperinsulinemia: inhibitors of phosphatidylinositol 3-kinase augment glucose-induced insulin secretion from islets of lean, but not obese, rats. Endocrinology 141:3287-3295

48. Kaneko K, Ueki K, Takahashi N et al (2010) Class IA phosphatidylinositol 3-kinase in pancreatic $\beta$ cells controls insulin secretion by multiple mechanisms. Cell Metab 12:619-632

49. MacDonald PE, Joseph JW, Yau D et al (2004) Impaired glucosestimulated insulin secretion, enhanced intraperitoneal insulin tolerance, and increased $\beta$-cell mass in mice lacking the p110gamma isoform of phosphoinositide 3-kinase. Endocrinology 145:4078-4083

50. Gao Z, Konrad RJ, Collins H, Matschinsky FM, Rothenberg PL, Wolf BA (1996) Wortmannin inhibits insulin secretion in pancreatic islets and beta-TC3 cells independent of its inhibition of phosphatidylinositol 3-kinase. Diabetes 45:854-862 